\title{
As origens do sentimento nacional boliviano em seu caminho à independência
}

Clayton M. Cunha Filho

$\overline{\text { ROCA, J. L. Ni con Lima ni con Buenos }}$ Aires: la formación de un estado nacional en Charcas. 2.ed. La paz: Plural Editores, 2011.

Em Ni con Lima ni con Buenos Aires, o historiador boliviano José Luis Roca (19352009) traça uma completa e detalhada história do convulsivo processo de independência do território que viria a ser a República da Bolívia (hoje Estado Plurinacional da Bolívia) tomando como fio narrativo as contradições geradas ainda durante o período colonial (e acentuadas ao longo do processo independentista) pela dupla submissão do território e seus habitantes à Coroa espanhola e aos vice-reinados titulares da sua administração, apesar da presença de um forte

\section{Clayton M. Cunha Filho}

Doutorando em Ciência Política pelo IESP-UERJ (ex-Iuperj). Assistente de pesquisa do Observatório Político Sul-Americano (OPSA/IESP-UERJ) e pesquisador do Observatório das Nacionalidades. sentimento autonômico local que serviria de embrião para sua imaginação nacional.

Antes da conquista espanhola, o império incaico conhecido em quéchua como Tawantisuyo, ou Reino das Quatro Regiões (Suyos), tinha duas das suas regiões (Qollasuyo e Antisuyo) abarcando boa parte do atual território boliviano. Tal império seria, após a conquista, reorganizado como Vice-Reino do Peru com sede em Lima em 1542, mas diante da vastidão do seu território e da necessidade de melhor administrar a imensa riqueza de prata descoberta em Potosí, a Coroa espanhola criaria em 1561 a Real Audiência de Charcas, com sede na atual cidade de sucre e abarcando o território do que viria a ser a Bolívia. Embora formalmente houvesse 
uma estrutura administrativa subordinada ao vice-reino do Peru e à Audiência já existente em Lima e com a declarada função primordial de aproximar a aplicação da justiça aos súditos locais, o fato de que a legislação colonial era em muitos pontos ambígua na divisão de jurisdições e que a criação de Charcas também tinha por função defender as riquezas de Potosí de ataques de invasores, sobretudo dos ainda insubmissos índios chiriguanos, fez com que na prática a autoridade da Audiência se sobrepusesse no âmbito local em muitos casos à do vice-rei e constituísse uma verdadeira experiência de autogoverno:

Debido a la gran distancia de la sede virreinal $\mathrm{y}$ al hecho de controlar la riqueza de Potosí que fue, durante largos períodos, la más cuantiosa del imperio colonial hispánico, la audiencia incursionaba en cuestiones administrativas, políticas y militares, convirtiéndose en un verdadero gobierno. Eso creaba fricciones permanentes con la audiencia pretorial y con el propio virrey [...] que veía disminuida su autoridad y menguada su jerarquía (ROCA, 2011, p. 73)
A existência dessa burocracia administrativa local dentro de cujas hierarquias a elite local podia exercer funções de governo, somada ao fato de que durante muito tempo saíam do seu território as maiores riquezas que sustentavam o próprio vice-reinado (do Peru até 1776 , depois o recém-criado Vice-Reino do Rio da Prata a partir daí) teria criado as bases da "comunidade imaginada" apontada por Benedict Anderson como primordial para a existência de uma nação. E seria a existência desse sentimento protonacional em Charcas a grande responsável pela constituição do território da antiga Audiência em república independente em fenômeno que se replicaria também nas demais repartições administrativas dos reinos de ultramar: a despeito dos grandes projetos de união e confederação alentados por Bolívar e outros, territórios como os da Audiência de Quito e das Capitanias da Venezuela e do Chile também caminhariam firmes para a consolidação das suas próprias independências nacionais apesar das suas eventuais ligações formais com vice-reinos cujas fronteiras originais se 
mostrariam impossíveis de manter diante dos sentimentos autonomistas locais.

Em um livro extenso (771 páginas) e extremamente bem documentado, Roca narra como as contradições do próprio processo independentista contribuiriam para acirrar esse legado autonomista colonial na medida em que a atuação de tropas auxiliares de origem estrangeira (sobretudo as dos quatro exércitos auxiliares enviados por Buenos Aires entre 1810 e 1817) no território do que viria a ser a Bolívia eram percebidas não sem motivo pela população local como ações de pilhagem e conquista por uma potência externa tão ou mais abominável quanto a submissão à distante e cada vez mais enfraquecida Coroa espanhola. A lógica inescapável da guerra de independência ditava às tropas independentistas a necessidade de buscar recursos de onde pudessem ser extraídos, como a Casa da Moeda de Potosí, e a empreender ações de terra arrasada quando precisavam bater em retirada desencadeadora de forte rechaço das populações locais que arcavam com o pior da devastação de uma guerra longa e arrastada.
Além disso, líderes independentistas locais como Miguel Lanza ou Manuel Ascencio Padilla que durante muito tempo representaram a única resistência local ao poder espanhol e controlaram partes do seu território nas chamadas "republiquetas" eram tratados como meros subordinados apesar do valor e lealdade demonstrados nos campos de combate, até serem abandonados à própria sorte quando os interesses portenhos já não tinham na libertação das "províncias altas" uma prioridade.

Roca busca também mostrar como a grande complexidade de questões em jogo (lealdade ao rei espanhol ou às cortes constituídas em sua ausência? Constitucionalismo ou absolutismo? Autonomia local ou independência? Monarquia ou república? Adesão a um vice-reino ou independência local?) determinou em muitas ocasiões os alinhamentos e adesões de importantes líderes locais que viriam a ser cruciais na consolidação do horizonte de independência plena do país. Assim é que com o fracasso dos exércitos auxiliares argentinos na libertação (e anexação Buenos Aires independente) de 
Charcas, o território voltaria a ser anexado ao Peru, então firme bastião realista. Mas o que a princípio seria celebrado por líderes realistas locais logo voltaria a exibir praticamente as mesmas contradições da submissão como contribuições forçadas ao esforço de guerra e tratamento como vassalo. Isto motivaria que líderes realistas como o general Pedro Antonio de Olañeta, que ademais era absolutista ferrenho, rompessem com o vice-rei peruano La Serna, utilizando-se de pretextos bizantinos como a adesão daquele à imposição pelas cortes de uma constituição liberal ao rei espanhol. No fundo, entretanto, o que buscava Olañeta era preservar os interesses socioeconômicos da elite charquense cansada da dupla submissão e dos encargos de uma guerra inacabável. O fato de que Olañeta depois flertasse com acordos com o Exército Libertador de Bolívar e Sucre, exigindo apenas ser tratado como o máximo mandatário do território da Audiência de Charcas, dá crédito a essa interpretação. As exigências, entretanto, foram consideradas demasiado altas para Bolívar, quem lhe oferecera a condição de aliado e membro pleno do Exército Libertador, mas jamais em qualquer posição de superioridade, o que selaria seu destino: praticamente todos os seus apoiadores (incluindo seu sobrinho e secretário pessoal) mudariam para o lado dos colombianos e Olañeta seria morto pouco depois na batalha de Tumusla.

Uma grande preocupação de Roca no trabalho é dessacralizar a figura de personagens históricos e compreendê-los como figuras de carne e osso, que tinham contradições entre seus interesses e seus ideais, e tratar de apresentá-las sem anacronismos e sem pré-julgamentos pelo modo como vemos hoje a causa pela qual diziam lutar. Assim, ele busca resgatar de acusações morais personagens como o sobrinho do general Olañeta, Casimiro Olañeta, um dos maiores artífices da influência da ideia por Sucre e posterior aceitação por Bolívar de uma nova república independente de ambos os anteriores vice-reinos, que durante muito tempo e ainda por muita gente é visto como um vira-casaca por supostamente ter sido defensor dos interesses espanhóis e aderido 
à causa da independência nos últimos momentos. Roca busca mostrar como dentro das opções disponíveis e cenários previsíveis as mudanças de alianças de vários dos personagens respondiam a deliberações perfeitamente racionais e que mesmo quando às vezes pareciam contradizer nobres princípios universais atendiam a interesses concretos e legítimos. E como mesmo por trás de nobres e grandiosos projetos de figuras como Bolívar por vezes se encontravam deliberações de realpolitik em defesa de interesses diretos de poder da sua nação colombiana.

O período narrado por Roca vai até, exatamente, a conclusão da presidência do marechal Antonio José de Sucre, primeiro presidente de fato da nova república independente da Bolívia (nome aliás escolhido como forma de massagear o ego do Libertador Bolívar e convencê-lo a aceitar a criação do novo país soberano), e cujo fracasso e queda teria tido a ver não apenas com interesses socioeconômicos contrariados por suas reformas liberais, mas também com as disputas de poder e influência sobre a nova república. A presença na presidência boliviana de uma figura como sucre era vista pelos líderes do Peru como um controle do país pelos interesses da Colômbia com quem logo entraria em uma guerra por disputas de fronteira. Da mesma forma, o pronto reconhecimento do novo país pelas Províncias Unidas do Rio da Prata, país que durante muito tempo procurou anexar as "Províncias Altas", tinha a ver com sua tentativa de atrair a Colômbia e as tropas de Bolívar, usando a Bolívia, a uma disputa com o Império do Brasil pelo controle da Banda Oriental que logo se tornaria o também independente Uruguai.

O livro de Roca é uma obra magistral e sem dúvida uma referência importantíssima, especialmente num momento como o atual, cheio de experimentações institucionais e tentativas de reimaginação nacional mediante a extinção da República de quase dois séculos e sua substituição pelo Estado Plurinacional. Finalmente, o ainda incerto experimento plurinacional atual busca reconhecer a dívida com seus povos indígenas, que, como mostra Roca, participaram ativamente das lutas do processo 
emancipatório do país, tendo sido mobilizados com promessas de cidadania e modernidade apenas para serem relegados a um papel de bestas de carga da sociedade crioula em um status muitas vezes pior até do que durante a colônia espanhola. Entretanto, embora o experimento atual declare aberta e orgulhosamente suas raízes nas centenárias lutas indígenas ao longo da colônia, durante o processo de independência e na própria república independente, o processo em curso se nutre também, embora nem sempre o admita, de uma longa tradição nacional - popular que tentou dar conta de efetivamente instaurar os "horizontes de camaradagem horizontal" (Anderson) prometidos pela nação e descumpridos pela República existente. E se por seus erros e contradições a tradição nacional-popular tampouco foi capaz de levar totalmente a cabo essa gigantesca missão, é precisamente pela natureza inacabada do projeto que deixou atrás de si que continua influenciando nos projetos do presente tal qual o Anjo da História de Walter Benjamin que é soprado ao futuro pelos ventos dos destroços do passado. E na medida em que o experimento atual tem essa raiz pluri, mas também nacional, parece ser fundamental conhecer as origens do fenômeno nacional na Audiência de Charcas e como este influenciou decisivamente os rumos da independência do novo país. Uma única e sentida ausência no monumental livro de Roca são os mapas, pois com tantas e detalhadas narrações de feitos históricos, batalhas e implicações geopolíticas dos novos Estados independentes que se formavam, estes poderiam ajudar a uma melhor visualização e apreensão dos lugares e conexões geográficas descritas. Contudo, esta crítica em nada nega os méritos desse livro que certamente se constituirá em referência fundamental da historiografia boliviana. 